219 カオス短期予測法を用いた強制減衰振子の予測制御

(制御性能向上のための数值的検討)

\title{
Predictive Control of a Forced Damped Pendulum Using a Short-Term Prediction Method Based on Chaos Theory (Numerical Investigations for Improvement of Control Performances)
}

\author{
○正 增本 憲泰（早大）正山川 宏（早大）
}

Noriyasu MASUMOTO, Waseda University, 3-4-1 Okubo, Shinjuku, Tokyo 169-8555, Japan

Hiroshi YAMAKAWA, Waseda University

Key Words : Vibration Control, Digital Control, Time Series Prediction, Predictive Control Forced Damped Pendulum

\section{1. 緒 言}

カオスなどの非線形現象は，機械システムにとっては好 ましくない現象であると考えられる場合が多く，そのよう な現象が現れないような設計がなされるのが一般的であ る。したがって, 通常の稼動条件下でカオス理論を積極的 に応用することが可能な機械システムは非常に少ない。し かし, カオス理論の応用技術の一つである時系列の決定論 的非線形短期予測法 (以下, 簡単にカオス短期予測法と称 する) であれば通常の機械システムにも応用可能であると 考え, 機械システムのリアルタイム振動制御手法の一つと してカオス短期予測法を用いた予測制御法を提示し，その 有効性を検討してきた(1)〜(4).

本研究では, 予測制御法を非線形系としてモデル化され る振子系の振れ角の振動制御問題へ適用し，カオス短期予 測法および制御入力算出法を改良することによって，振れ 角が非周期的で非常に複雑な挙動を示す場合の制御性能を 従来よりも向上させることを目的とした，振子は，支持点 に水平方向の周期的な变位入力が作用する強制減衰振子と し，制御入力はカオス短期予測法によって算出される数ス テップ将来までの振れ角の予測值を用いて算出した。計算 結果より, 従来手法よりも制御性能が向上し, 改良手法の 有効性が示された。

\section{2.カオス短期予測法}

カオス短期予測法は, 主としてカオス時系列の高精度の 短期予測を行うために開発されてきた時系列の予測法であ る.これまでにいくつかの手法が提示されてきたが(5) -(8), 本研究で用いるカオス短期予測法は, 機械構造系のリアル タイム振動制御手法への応用を前提としたもので,このよ うな用い方をする場合には従来の手法では十分に対応でき ない、そこで，筆者らによって以下 4 つの考え方が新たに 導入された。

（1）最適サンプリング周期 $\tau$

(2) 前方地平線 $h_{f}$

(3) 統一埋め込み次元 $K e^{*}$

(4) 後方地平線 $h_{b}$

これらの值は予測制御を開始する前に予測対象時系列のサ ンプルより算出される定数であり，ある程度の精度を保ち ながら予測値を高速に算出するために有効であると考えら れる，各値の意味や算出法の詳細に関しては既報(1) (4)を参 照されたい.
この予測法を用いることにより，予測対象時系列 $\{X\}$ の 既知デー夕列 $\left\{X^{*}\right\}=\left(x_{1}, x_{2}, \cdots, x_{n}\right)$ から $h_{f}$ ステップ将来ま での予測值 $\hat{x}_{n+\lambda}\left(\lambda=1,2, \cdots, h_{f}\right)$ を算出することが可能と なる．以下，記号へを用いて予測值を表記する。本研究で は，前述の 4 項目に部分時系列の考え方(2)を加えることに よって，予測精度の向上をはかった。

\section{3. 強制減衰振子}

$3 \cdot 1$ 対象モデル 本研究で対象とする強制減衰振 子の物理モデルおよび設定した各パラメー夕の值をそれぞ れ図 1 と表 1 に示す. 振子は質量 $m$ の剛体と仮定し, その 支持点 $O^{\prime}$ に周期強制変位入力が水平方向に作用する場合 を考える．点 $G$ は振子の重心である．また，支持点におけ る摩擦力は無視し, 比例粘性減衰のみを考慮する。この場 合の振子の運動方程式は,

$$
I_{O^{\prime}} \ddot{\theta}+c l^{2} \dot{\theta}+m g l \sin \theta=m A l \omega^{2} \sin \omega t \cos \theta \cdots(1)
$$

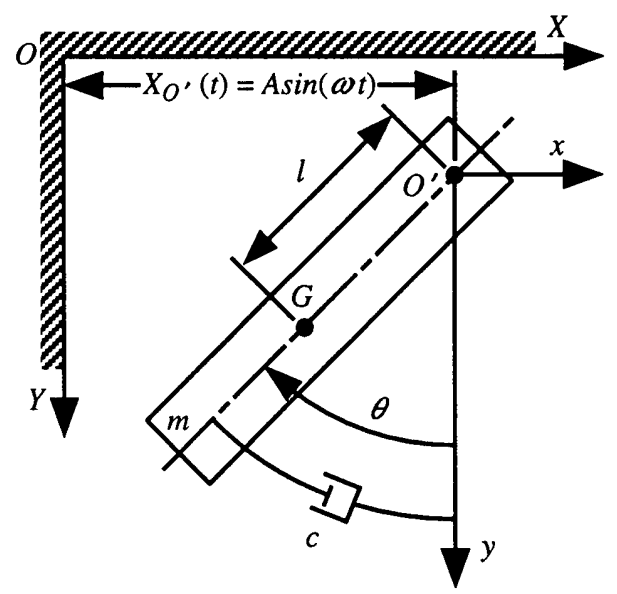

Fig. 1 Model of the forced damped pendulum

Table 1 Parameters for the pendulum and the excitation

\begin{tabular}{lcc|l}
\hline \hline Mass of pendulum & $m$ & $\mathrm{Kg}$ & $8.44 \times 10^{-2}$ \\
Distance between $O^{\prime}$ and $G$ & $l$ & $\mathrm{~m}$ & $9.20 \times 10^{-2}$ \\
Moment of inertia around $O^{\prime}$ & $I_{O^{\prime}}$ & $\mathrm{kgm}^{2}$ & $9.98 \times 10^{-4}$ \\
Damping coefficient & $c$ & $\mathrm{Ns} / \mathrm{m}$ & $6.50 \times 10^{-1}$ \\
Forced amplitude & $A$ & $\mathrm{~m}$ & $12.7 \times 10^{-2}$ \\
Forced angular frequency & $\omega$ & $\mathrm{rad} / \mathrm{s}$ & 15.7 \\
\hline
\end{tabular}

〔No.01-10〕日本機械学会第14回計算力学講演会講演論文集〔2001-11.28～30・札幌市〕 
となり，振れ角が大きく線形系として近似できない場合を 対象とする. 重力加速度は $g=9.81 \mathrm{~m} / \mathrm{s}^{2}$ を用いる。本研 究では振れ角 $\theta$ の時系列を予測対象とする。

$3 \cdot 2$ 制御入力 筆者らの予測制御に関する一連の 研究では, 制御入力 $\boldsymbol{u}$ を

$u(t)=u_{p}(t)+u_{f}(t)$

のように予測制御入力 $u_{p}$ とフィードバック制御入力 $u_{f}$ の 和として定義している。て は前出の最適サンプリング周期 である。ここで, $u_{p}$ は

$$
u_{p}(t)=\sum_{i=0}^{h} \Omega_{i}^{T} \widehat{w}(t+i \tau) \text {. }
$$

のように $h_{f}$ 個の外乱の予測值 $\widehat{w}$ の線形和と仮定する. $\Omega_{i}$ は重みである。式(1)に近似式

$$
\left\{\begin{array}{l}
\ddot{\theta}(t) \fallingdotseq \frac{\dot{\theta}(t+\tau)-\dot{\theta}(t-\tau)}{2 \tau} \\
\dot{\theta}(t) \fallingdotseq \frac{\theta(t+\tau)-\theta(t-\tau)}{2 \tau}
\end{array}\right.
$$

を適用すると，外乱項と考えられる式(1)右辺は

$$
\begin{gathered}
m A l \omega^{2} \sin \omega t \cos \theta(t)=\frac{I_{O^{\prime}}}{4 \tau^{2}} \theta(t+2 \tau)+\frac{c l^{2}}{2 \tau} \theta(t+\tau) \\
-\frac{I_{O^{\prime}}}{2 \tau^{2}} \theta(t)+m g l \sin \theta(t)-\frac{c l^{2}}{2 \tau} \theta(t-\tau)+\frac{I_{O^{\prime}}}{4 \tau^{2}} \theta(t-2 \tau) \\
\ldots \ldots \ldots \ldots \ldots \ldots \ldots(5)
\end{gathered}
$$

となり, 時刻 $t$ の外乱值は $\theta(t+i \tau)(i= \pm 2, \pm 1,0)$ から算出 される. 本研究では, 式(5)の右辺に振れ角の予測值 $\hat{\theta}$ 用 いることによって外乱の予測值 $\widehat{w}$ 算出する．従来は，角 速度の時系列をも予測対象としていたが，振れ角との整合 性が保たれないという問題があった。 $u_{f}$ は既存の線形 フィードバック制御理論より算出し，ここでは式(1)を $\theta$ 微 小の条件で線形化した系

$$
I_{O^{\prime}} \ddot{\theta}+c l^{2} \dot{\theta}+m g l \theta=m A l \omega^{2} \sin \omega t
$$

に対するフィードバックゲインを用いる。

\section{4. 計算結果}

表 1 に示した諸条件のもとで振れ角のサンプル時系列を 生成し，その時系列に対して行った時系列解析の結果を表 2 に示す。図 2 に制御結果を示す。図 2 より，振れ角，角 速度共に制御性能が向上していることが示される。また， この制御性能は長期的に保持されることを付記する。

\section{5. 結言}

本研究では，カオス短期予測法を用いた予測制御法を， 支持点に水平方向の強制変位入力を受ける強制減衰振子系 に適用し，制御性能の向上のための数値的検討を行った。 予測值算出法および制御入力算出法を改良することによ り，振れ角時系列が非周期的で複雑な挙動を示す条件下に おいて従来よりも制御性能が向上し，改良手法の有効性の 一端が示された。

Table 2 Results of time series analyses

\begin{tabular}{ll|c}
\hline \hline Optimum sampling period & $\tau$ sec & $5.00 \times 10^{-2}$ \\
Forward horizon & $h_{f}$ & 7 \\
Unified embedding dimension & $K e^{*}$ & 4 \\
Backward horizon & $h_{b}$ & 1835 \\
\hline
\end{tabular}

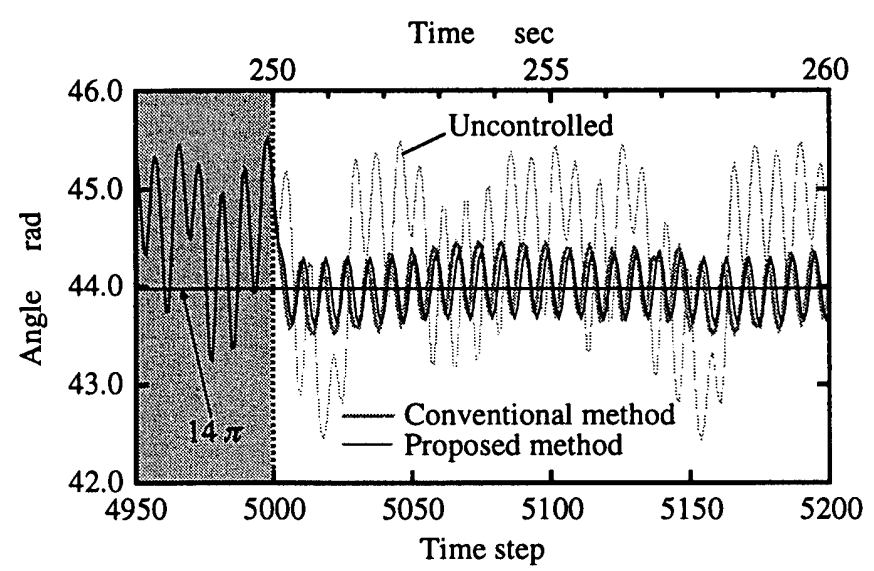

(a) Swing angle

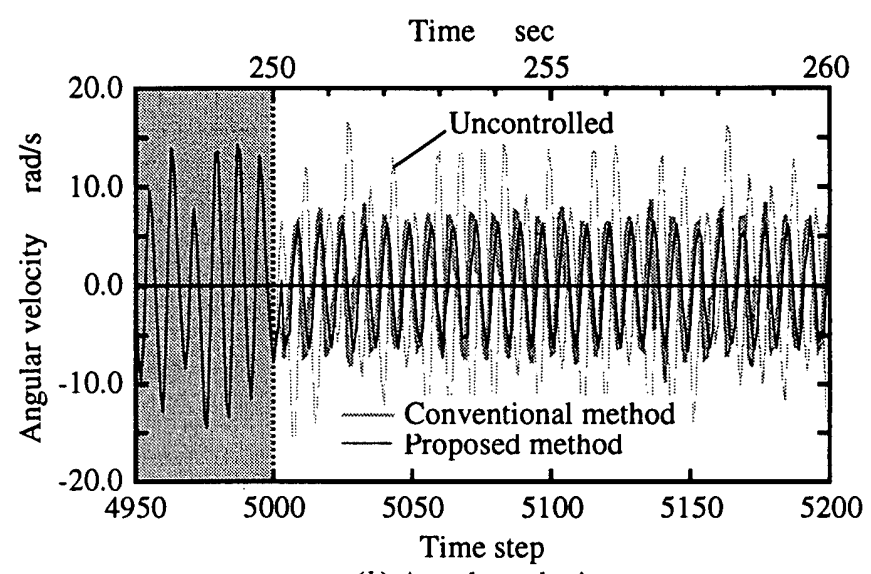

(b) Angular velocity

Fig. 2 Control results

\section{文献}

（1）増本·山川，カオス理論に基づく短期予測法を用いた予 測制御に関する研究 (複数の予測出力值を用いた非線 形系の予測制御)，機講論, No. 00-1-(I) (2000-8), 867868.

（2）増本・山川, カオス理論に基づく短期予測法を用いた予 測制御に関する研究 (複数の予測外乱値を用いた予測 制御法), 機論, 66-650, C (2000), 3320-3327.

(3) Masumoto, N. and Yamakawa, H., Predictive Control of Nonlinear Mechanical Systems Using a Short-Term Prediction Method Based on Chaos Theory (Applications to a Forced Pendulum), Proc. the 2000 ASME International Mechanical Engineering Congress and Exposition, AD-61, (2000), 165-172.

（4）増本・山川, カオス理論に基づく短期予測法を用いた予 測制御に関する研究 (複数の予測出力值を用いた予測 制御法), 機論, 67-655, C (2001), 704-711.

(5) Farmer, J. D. and Sidorowich, J., Predicting chaotic time series, Phys. Rev. Lett., 59-8 (1987), 845-848.

(6) Casdagli, M., Nonlinear prediction of chaotic time series, Physica D, 35 (1989), 335-356.

(7) Sugihara, G. and May, R. M., Nonlinear forecasting as a way of distinguishing chaos from measurement error in time series, Nature, 344 (1990), 734-741.

（8）合原編, カオス時系列解析の基礎と応用, (2000), 産業 図書. 